\title{
CiRCULAR CONCEPT OF TIME \\ IN LEE MARACLE'S RAVENSONG \\ AND TOMSON HIGHWAY'S \\ KISS OF THE FUR QUEEN
}

Brno Studies in English

Volume 46, No. 1, 2020

ISSN 0524-6881 | e-ISSN 1805-0867

https://doi.org/10.5817/BSE2020-1-9

\section{MICHAt KAPIS}

\begin{abstract}
The paper analyses two novels by Aboriginal Canadian writers, Kiss of the Fur Queen by Tomson Highway and Ravensong by Lee Maracle. The main focus of the analysis is the representation of time in the texts. The paper examinates specific examples from the novels, where time is depicted as being circular rather than linear. Circular time is measured by cyclical events: passing seasons, migrations of animals, or births and deaths. The past determines the future and provides guidance for the present. The Western linear time may be therefore seen as less natural, a broken circle, stretched out in a straight line to accommodate for the precise though unrepeatable dates. The paper identifies the techniques and strategies used by the authors to depict the circular time in the novels. It also raises questions about the possible purposes of introducing the circular perception of time into a narrative.
\end{abstract}

Key words

Indigenous Canadian literature; Lee Maracle; Tomson Highway; circular time; orality; repetition; oralised literature

\section{Introduction}

Time has always been one of the greatest mysteries for humankind. Scientists, philosophers and poets alike have attempted to discover and explain its principles. In the struggle to understand time, people invented calendars. Hourglasses and clocks have been created to keep track of it. Nevertheless, to a large extent, time remains unfathomable till this day. Despite its shapeless, evanescent, impalpable nature, every person is somehow aware of its existence. This indefinable characteristic of time surely led to confusion among thinkers who partook in time-related pondering. The current, Western perception of time spread with the advent of the three Abrahamic religions: Islam, Judaism, and Christianity. Everything was created by one God, therefore time itself has to have a beginning and an end (Cahill 2010: 251). This concept was then represented graphically, in the form of a line. Since then, lines have become a commonly accepted method of visualising the passage of time; especially in the Western cultures, they are inherently tied to any historical discourse. However, the linear perception of time is not the only existing model.

While Western philosophers were deliberating the nature of time, the Indigenous peoples of the Americas, Australia, Oceania, and Africa had their own ideas about the fourth dimension. For them, time was naturally made up of 
repeated, observable events, such as the seasons of the year, the journey of stars in the night sky, or the migrations of animals. The past, the present and the future were all connected with something more than just a straight line. Time was perceived as a circle. To this day, the imagery of a circle remains a vital element of many Indigenous worldviews and philosophies around the world. Imani (2012: 104) writes about the conceptions of time in Southern Africa. One of the examples he provides are spiritual healers who commune with their ancestors to gain access to healing powers. Imani interprets this as an act of invasion from the past to the present. Donaldson (1996) provides a similar insight into the culture of the Aboriginal peoples of Australia, who used to pay great attention to the proper observance of the ceremonies associated with the annual cycle of seasons. It was believed that any deviation from the repeated traditions could result in famine, deluge, drought, or disease (Donaldson 1996: 192). Finally, in the North American context, Donald Fixico (2013: 1) of the Seminole and Muscogee Creek peoples introduces the concept of "Indian Thinking", which he defines as "seeing' things from a perspective emphasizing that circles and cycles are central to the world and that all things are related within the universe." He emphasises the Indigenous belief in the interconnectedness of all living things on the planet and the resulting accountability for damage dealt by humans to the environment. What is more, Fixico (2013: 5) also explains the importance of cyclical time for oral traditions. He sees storytelling as "reviving an experience of the past that becomes alive again, thereby transcending time from the past to the present."

The cyclical time was at one point the dominant paradigm around the world. It was the standard perception of time in many ancient civilisations, including Egypt and Greece (Whitrow 1989). Niehaus (2013) argues that the line was fully separated from the circle only after the invention of mechanical clocks. Until then human lives were still organised according to the natural cycle of time, with the promise of eternal, time-transcending life in heaven looming somewhere above them, just outside their reach.

Today, in a world tightly connected by technology, those two concepts of time exist alongside each other. Different cultures still subscribe to different understandings of time. There is also a strong connection between a culture's view on time, orality, and literacy. The deviation from the circular perception of time, which is observable and based on natural events, came with the development of writing, a technology which allowed people to record the passage of time. Walter Ong (1982: 77) argues that writing is able to restructure consciousness. Living in a literate society, where writing is a vital skill, conditions the way a person perceives the world, including time. That is why the circular perception of time is mostly associated with primary oral cultures, in which writing is not (or was not until recently) a widespread medium of communication. These cultures depend on oral tradition for preserving their history. Another important characteristic of primary oral cultures is the belief in the high value of community. Speaking connects and unifies people, whereas writing distances and isolates them (Ong 1982: 72-73). The circular perception of time, oral tradition, and a strong sense of community are all deeply interconnected. 
One of the media in which these ideas become especially apparent is literature. Indigenous authors include elements inspired by oral tradition in their writing. This is also true about oral concepts. Both the content and the style of writing may be used to add features of orality to the text, in a process which may be called "oralisation" of literature. By oralising their texts, Indigenous authors emphasise the oral roots of a story, and differentiate their writing from nonIndigenous literature. The circular perception of time in a text may be seen as one of these orality features. Storytelling, more often than not, requires a time frame for given events to take place in. Indigenous Canadian literature specifically, provides a lot of interesting material for analysis, especially since authors often speak about their ideas and inspirations in interviews. This article examines how cyclical time is represented in two novels by Indigenous Canadian writers: Lee Maracle's Ravensong and Tomson Highway's Kiss of the Fur Queen. The novels were published in 1993 and 1998 respectively. Both authors are Native Canadian, and both of them use their Indigenous heritage and individual experience as sources in their writing. Neither of the novels talks specifically about time and, at first glance, it may seem that they are completely different. However, the texts share many similarities, also in the manner in which time is depicted. The authors provide multiple examples of literary techniques that may be used in order to convey the concept of cyclical time, however, since time is not the primary or even secondary focus of these novels, they have not yet been analysed from this perspective.

\section{Intertwining cycles in Lee Maracle's Ravensong}

Lee Maracle belongs to the Coast Salish First Nation of Canada. She is one of the most renowned Canadian authors, who tackles issues such as racial and economic inequality or sexism in her writing. She is also a widely respected activist, teacher and public speaker. In her many essays and interviews that she has given, she confirms using her Indigenous culture and worldview as inspiration for her writing (Fee and Gunew 2004, Hancock 2015, Cullingham 2016). Her notable works include Bobbi Lee: Indian Rebel (1975), Ravensong: A Novel (1993), Daughters are Forever (2002), and others.

Ravensong tells the story of two communities living on the opposite sides of a river. The communities are divided due to their race (one is Indigenous and the other is white), economic status, culture, and lifestyle. The novel explores the similarities and differences between the two groups, describing various events which result in either deepening of the divisions or bringing the people together. The main character is a teenage girl named Stacey. She is a member of the Indigenous community, but attends a white school across the river. As such, the character serves as a bridge between the two groups and has an introspective view on both of them. There are not many direct references to the passage of time within the novel. The epilogue reveals that the described events take place in the year 1954. The epilogue itself is set twenty five years later. Despite the fact that the exact time of the events is only revealed at the very end of the novel, in the 
very first scene the reader may already suspect how integral the idea of time is to the story. The novel opens with a description of a funeral. One of the characters present there is a young girl named Celia, who, as it turns out later, has a strong connection with the spiritual world. At the time of the funeral, Celia is having a vision. She travels in time and space to witness one of the first encounters between her distant ancestors and European travellers. Indigenous women are sent aboard the European ship, objectified to serve as gifts for the outlanders. It is implied that they are exploited sexually. Celia does not fully understand what she sees due to her young age. However, it is clear that through her vision she is in the present and in the past at the same time:

Everything non-physical inside her sped up. The song played about with the images inside. She stared blankly at some indefinable spot while the river became the sea, the shoreline shifted to a beach she couldn't remember seeing, the little houses of today faded. In their place stood the bighouses of the past. (...) She drifted, floating into some confusing state of numb being in which the sounds she heard earlier whirred, disjointed from reality. Pictures floated up from her guts, hazy then sharpening with the growing intensity of her reverie. Odd pictures, disconnected at first, wheeled around in her mind, forming a web of knowing she was too young to understand. Somewhere else, in some other time men were digging, singing desperately, rushing through the digging, hurrying through the song. $(10,14)$

The fragment above illustrates the unusual relation between time and events in the novel. It is with the use of repetitions, however, that the author truly brings forth the idea of circular time.

Repetition is an essential tool in conveying the concept of time as an endless cycle. In a physical sense, any object which travels on a circular path is bound to repeat its journey at some point. As a literary device, repetition has been identified to be an element of particular importance in orature. Walter Ong, one of the most renowned scholars in the field of orality studies, explains the role of repetition in a primary oral culture. In the world where writing is a skill possessed only by the privileged few, memory remains the only viable method of preserving information. By repeating the same thing over and over again, people increased their chances of remembering it later. The technique became especially vital for poets, who had to declaim long epic poems from memory. For instance, the inclusion of repetitive patterns in Iliad and Odyssey made them much easier to recite (Ong 1982: 20-25).

The importance of repetition goes even further than literature. Eber Hampton, a Chickasaw scholar, talks about an iterative structure of thought, which is characteristic for Native Americans, but also writers from non-European countries all over the world. Hampton's argument "progresses in a spiral that adds a little with each thematic repetition rather than building an Aristotelian argument step-by-step." He explains that although this type of writing is often criticised as repetitious, he was always able to find "new meaning in each turn of the spiral" (Hampton 1993: 6). 
Upon a careful read, one may notice that Ravensong features a number of ideas and phrases which are repeated throughout the novel. They are mentioned by different characters in different situations and could be seen as morals, mantras, or even refrains. Two of these phrases stand out as used most often. These are "Too much Raven" and "No use thinking about." The former appears first on page 107 , in the scene where Stacey tells her mother how she stood up to the principal of her school. Her mother comments with the phrase "Too much Raven" followed by laughter. The words then reappear at multiple points in the novel with reference to behaviour that is perceived as silly, peculiar or assertive. They echo for the final time in the epilogue. Stacey's son asks her why they paid attention to white people's regulations and prohibitions. The answer is "Not enough Raven" - a twist on the original phrase. The words have their own important meaning for the plot of the novel. Within the context of circular time, however, they mark repeatable situations. It is worth noting that the circular perception of time does not require all events to be repeated exactly in the same manner. The cycle leaves a lot of room for unique occurrences. Nevertheless, the underlying framework of events is repeatable.

"No use thinking about" is an intrusive comment disturbing Stacey's thoughts whenever she tries to ask herself too many questions. The girl hears it as spoken by Old Nora, the character whose funeral is described in the opening chapter:

Most of the kids at school rarely saw their relatives. In fact, few had relatives that lived anywhere close enough to visit on any sort of regular basis. Who did they play with when they were small? she wondered.

Nora's voice interrupted her thoughts: "No use thinking about." (17)

It is then used several times in similar contexts. Old Nora herself is one of the few characters who might be seen as markers of circular time in their own right. Stacey is shown to be in a way obsessed with deceased people. Her thoughts return to Old Nora on multiple occasions. Even though the novel opens with Nora's funeral, the elder is still an integral part in the plot, as Stacey reaches to her for guidance and attempts to understand Nora's life. There is, however, one character who even more prominently haunts Stacey's thoughts. At the beginning of the novel, one of the main character's classmates, Polly, commits suicide after the rest of the class discovers that she had sex with one of the boys. Stacey is for a long time unable to understand the reasoning behind Polly's decision, as the very idea of taking one's own life seems foreign to her. Furthermore, as Stacey has been brought up in a different culture, she perceives sexuality differently from her classmates. For her it is not considered a taboo, which makes it even more difficult to make sense of Polly's actions. Although the two girls were not close friends, Stacey cannot let go of thinking about Polly. There are only a few chapters in the novel, in which Nora and Polly are not mentioned.

Polly's suicide is also essential in the epilogue to the novel. In the final paragraphs, it is revealed that Stacey's nephew, Jimmy, also committed suicide some 25 years after the main events of the novel. The main character's son, Jacob, attempts to understand the reasoning behind this, just like his mother did over two 
decades earlier. Another circle of time is completed and the events are repeated again. In response to Jacob's questions, Stacey tells him the whole story that the reader has just finished reading. The epilogue becomes the beginning and the end of the story simultaneously:

The story had begun as an answer to her son's question, "Why did little Jimmy shoot himself?" Her nephew has shot himself. The dilemma of Polly had revisited Stacey. In trying to answer the question with a story she felt the necessity to recapture the lost sense of community that lay wounded in the shape of Jimmy's suicide. It took all winter for Celia, Stacey, Momma and Rena to recount that summer. Young Jacob sat in silence listening to the women. (197)

The above fragment truly captures the essence of the circular perception of time. The cycle might not be visible until the very end of the novel. However, it is promptly recognisable as soon as the two ends of the plot meet, forming not a line, but a circle.

Storytelling seems to be especially important for the Indigenous community in Ravensong. There are many instances in the novel, where characters repeat stories to each other. These stories often serve educational purposes, but are sometimes also used as an entertainment or a way to convey news in an indirect manner. Whatever their goal, stories are a constant element in the novel, and may be seen as yet another indication of the circular nature of time:

While she cooked and cleaned for him Grampa kept up a steady stream of talk, mostly stories. Momma liked the stories. She repeated them to her children during the long winter nights in which she sat 'round the stove knitting thick socks for her small family and some of the old people too frail to do their own knitting. (...) When she was on a roll with some story or other she stood up and assumed the beauty and cadence of Speaker. Her eyes were large and shaped like Raven's, snappy and black, her skin dark but her hair auburn, almost red. (98)

Storytelling lies at the heart of the community. Each person tells a story slightly differently, which is why it becomes possible to listen to the same story over and over again without getting bored. This also is a characteristic feature of the circular perception of time. It is not necessary for every single word of the story to be repeated in the exact same fashion. The very act of repeating a story is part of the circle, even if the story turns out to be much different than its original version. Storytelling brings the community closer together, which for many people is the basis of survival. People in a close-knit community help each other out, especially in a time of crisis, such as an epidemic. After Stacey's village is hit with influenza, those fortunate enough not to get sick spend all their energy helping the afflicted. The role of children is vitally important as well. They are considered to be the building blocks of the community. After one generation dies, their children carry on, sustaining the community's life. They are a necessary part in 
the cycle of revival and recreation. Individuals are not able to properly function without the support of the community. After the community is dissolved, isolated members struggle with a sense of emptiness. Both in the case of Ravensong and Kiss of the Fur Queen severing community bonds leads to depression and eventual death. In Ravensong it is little Jimmy who pays the highest price.

Even Stacey's plans for the future are based on a circle:

Stacey carefully explained the business of Indian Day Schools. Their reserve had enough kids to qualify for one and she would graduate four years after high school eligible to run the school. The women all talked at once, firing questions at her. What are they going to do with the residential schools. Will there be proper religious instruction? What about the learning, will it be the same as what white kids get? (59)

Stacey's dream is to build a school in her home reserve, to provide Indigenous children with proper education, without the need of sending them to residential schools, where they were separated from their parents and their culture. She is being taught to become a teacher herself. The young replace the old in order to educate the youngest. One generation passes away but another continues their work. Although Stacey's plans never fully come to fruition, she does want to keep the community together.

Dadey (2003) attempts to look at Ravensong using the Bakhtinian theory of dialogism. Bakhtin argues that a linguistic utterance is partly defined by the speaker's anticipated response. In his theory, a dialogue, which consists of encoding, transmission, and decoding, creates a circle, all elements of which are interconnected. Dadey applies that theory to Ravensong. He provides several examples from the novel, in which a character's dialogue is conditioned by an anticipated response. One of these examples concerns the relationship between Stacey and a white boy named Steve, who imposes his presence on her, and walks her home without asking her permission. The girl is doubtful of his intentions, and does not truly want to engage in any conversation. However, she refrains from saying that, because she predicts that he would shame her in return. She is also unable to refuse him, due to the lack of initial question. In this situation, both Steve's behaviour and the anticipated response dictate her utterance. In Dadey's words, "his initial silence has in turn silenced her." (Dadey 2003: 119)

Dadey also applies Bakhtin's theory to oral tradition as a whole. In oral tradition, he explains, a story is defined by the speaker as much as the listener (Dadey 2003: 111). Storytelling is a reciprocal act, which again invokes the imagery of a circle. At the same time, storytelling may be seen as being constant and having neither a beginning nor an end. Leslie Marmon Silko explains oral tradition from a Pueblo Indian perspective:

Because storytelling lies at the heart of Pueblo culture, it is absurd to attempt to fix stories in time. "When did they tell the stories?" or "What time of day does the storytelling take place?" - these questions are nonsensical from a Pueblo perspective, because our storytelling goes on constantly: as 
some old grandmother puts on the shoes of a child and tells her the story of a little girl who didn't wear her shoes, for instance, or someone comes into the house for coffee to talk with a teenage boy who has just been in a lot of trouble, to reassure him that someone else's son has been in that kind of trouble, too. Storytelling is an ongoing process, working on many different levels. (Silko 1996)

Oral tradition may therefore be seen as one, never-ending circle or, as Silko puts it, an intricate spider web, on which every individual point is masterfully woven to be a part of the whole.

Finally, the discussion of time in Ravensong would not be complete without mentioning Raven herself. Raven is often identified as a personification of the trickster - a demigod possessing the power to take any shape or form, watching over Native communities, while at the same time playing tricks on them. However, in an interview with Jennifer Kelly, Lee Maracle expands this interpretation:

Raven is referred to a lot as trickster, which I think is a simplification of who Raven is for us. Raven is the harbinger of social transformation. Raven sings when the world itself is amiss. (...) And what Raven does when she sings is tell us that it's time, that the time is coming and to listen to what's going on in a whole bunch of different ways - listen to it spiritually; listen to it emotionally; listen to it intellectually; listen to it physically; listen to what's going on - listen to it socially, and personally, and in family ways; listen to it in a number of different ways.

(Lee Maracle in Kelly 1993: 85-86)

The Raven in Ravensong is definitely an herald of change. She appears regularly throughout the novel, usually in the company of another supernatural character, Cedar. It is heavily implied that the epidemic which befalls the Native people is of Raven's doing. The trickster desires to bring the two communities together by forcing one group to seek help with the other. In terms of circular time, there are two reasons for Raven's significance. First, she appears very regularly, commenting on events and conversing with Cedar. The story goes back to these characters over and over again, making them almost a refrain to the plot. This once again brings about the image of a circle. Second, the epidemic caused by Raven is given a broader context in the epilogue:

She could not stop recounting the number of dead babies from epidemic after epidemic and multiplying the numbers of children those babies would have had: 1840 - 100 dead childless children, smallpox. 1885 - 37 dead childless children, diptheria. 1905 - 57 dead childless children, measles... A sound came up - ravensong, powerful almost inhuman... 1918 - 93 dead childless children, influenza. Memory after memory pushed up the sound. She imagined the faces of the babies these children might have had and she calculated their numbers. 1920-1940 tuberculosis, 157 dead childless children. (198) 
Stacey herself notices how gruesomely the history repeats itself. The epidemic described in the novel was only the latest one in the long and painful history.

Although time may not be the central topic of Lee Maracle's Ravensong, it is certainly relevant to the story. The circular perception of time shines through the descriptions of events. It is subtle in some instances, explicit in others. However, it is clearly an important part of the novel's structure and plot.

\section{The haunting past in Tomson Highway's Kiss of the Fur Queen}

Tomson Highway is a member of the Cree nation. He was born on the border of the Manitoba province and the Nunavut territory in Canada. He is an acclaimed playwright, songwriter and novelist. His most important works include the plays The Rez Sisters (1986) and Dry Lips Oughta Move to Kapuskasing (1989), as well as the 1998 best-selling novel Kiss of the Fur Queen.

In a published lecture entitled "Comparing Mythologies", Highway explores similarities and differences between Christian, Greco-Roman, and North American mythologies, and discusses the perception of time in various cultures. He defines mythology as a halfway point between truth and fiction. Furthermore, he explains that in both Greek and North American mythologies, time was perceived as a circle:

And on that circle-of time (...) there is no beginning, there is no middle, there is no end. Existence in the universe is merely one endless circle of birth and life and death and re-birth and life and death and re-birth and life and death so that those who lived in times before us-our mothers, our grandmothers, our great-great-grandmothers, those children of ours who have died, those loved ones-they live here with us, still, today, in the very air we breathe, in the shimmer of a leaf on that old oak tree, in that slant of sunlight that falls in through your window and lands on your wrist. (Highway 2003: 44)

However, the temporal circles were broken by an intrusion of another worldview. For the Romans, the change came with the birth of Christ. In the case of North America, it was the European conquest that left the circle half-broken. The circular and linear perceptions of time blended together. The same is also apparent in Highway's novel.

Kiss of the Fur Queen is a moving account of the lives of two brothers, Champion and Oneemeetoo Okimasis. The boys are born into a Cree family, but have to attend a residential school, where they are torn from their heritage. Their hair is cut and their names are changed to Jeremiah and Gabriel. They are also physically and sexually abused by a priest at the school. While struggling to adapt to their new reality, they are able to cultivate their passions. The residential school gives them access to the previously unknown European culture. Jeremiah falls in love with the piano and classical music and eventually becomes a musician. Gabriel pursues the career of a dancer, fascinated by ballet. However, the scars of 
their childhood haunt them throughout their lives, indirectly leading to Gabriel dying of AIDS by the end of the book.

The novel touches upon many important issues, such as discrimination, identity crises, or child abuse. Although it also describes fictional events and characters, much of the story is autobiographical. The perception of time might, again, not be the focal point of the story. However, just like in the case of Ravensong, a closer inspection reveals the underlying temporal circle.

The story begins in February 1951 and finishes in 1987. In terms of linear time, that is 36 years, during which the two main characters were born and grew up. These 36 years are described on 306 pages dense with symbolism. Similarly to Ravensong, the circular perception of time in the novel is first apparent in a character's vision. At the moment of Champion's conception, his mother Mariesis travels back in time:

Suddenly, the light was coming from the Fur Queen's eyes, Mariesis halfclosed hers and let this moment take her, out the little window above the bed, out past the branch of the young spruce tree bending under its weight of snow, out to millions of stars, to the northern lights: the ancestors of her people, ten thousand generations, to the beginning of time. Dancing. (...) And though barely audible where she lay in her pool of perspiration, the women's voices said to her: "And K'si mantou, the Great Spirit, held the baby boy by his big toe and dropped him from the stars..." (19)

This powerful fragment embodies the essence of cyclical time. Mariesis is physically in the present, but she has a vision of the past, where she sees her ancestors. At the same time, she hears a prophecy for the future. She knows that she is going to give birth to another child. The past, the present, and the future are all interconnected in a single scene. The novel is filled to the brim with similar descriptions, and Highway's Indigenous heritage is constantly at the front of it all.

Repetitions once again play an important role in depicting the circular perception of time. Highway uses a notable number of Cree words in his novel, with a glossary included at the end. Some of these words are repeated multiple times. The boys' father Abraham Okimasis is known for his yodel of encouragement: "Weeks'chiloowew!" meaning "the wind's a-changing!" The phrase echoes throughout the novel, even after Abraham's death, as his children are reminded of it in various contexts and situations, and also use it to express excitement. Nevertheless, Jeremiah has a recurring phrase of his own. His first composition "Ateek, ateek, astum, astum" is performed several times throughout the novel. It becomes a symbol of his connection to the Cree heritage. In the process of attaining education, Jeremiah loses interest in his humble beginnings, fascinated by Western composers. Towards the end of the story, he recognises his mistake, which is marked by another performance of his original song. In this way, his career as a musician comes full circle. It might seem that the circular time counteracts all progress. Characters might seem to be cursed with a never-ending cycle of pointless drudgery. However, that is not necessarily the case. It is true that Jeremiah returns to the starting point, but he is still a changed man. His fascination with 
European classical music turns him into a virtuoso who, upon rediscovering his heritage, may put his well-developed skills to use. Time may be a circle, but the circle keeps rolling on.

Another defining cycle in Kiss of the Fur Queen is the cycle of life and death. The reader witnesses the conception and birth of both Jeremiah and Gabriel, as well as the death of Abraham and Gabriel. There are, naturally, many similarities between the boys and their father. Abraham is well known for his skills of playing the accordion. Jeremiah follows in his father's footsteps, discovering the world of music himself:

For wasn't it the greatest pride to have finally sired a child with a gift for the making of music, one to whom he could pass on his father's, his grandfather's, and his great-grandfather's legacy? The assurance that this ancient treasure of the Okimasis clan could rest intact for at least another generation inspired him to glide across the ice with even greater skill, greater precision, greater speed. (27)

Jeremiah's musical talent inherited from his father is another iteration of the same cycle. Through tireless practice Jeremiah attempts to become the best of the best. He desires to repeat Abraham's success in the World Championship Dog Derby, and win a trophy of his own. He becomes obsessed with this goal and eventually enters a competition to realise it and he wins:

Hands reached for him, clutched at his arms, his shoulders, his back. Champagne glasses, cameras, microphones were aimed at him. Men with notepads and pencils, women with pens and large red moving mouths, babbling in this language of the Englishman, hard, filled with sharp, jagged angles.

Something about "Jeremiah Okimasis, twenty years old." Something about "Jeremiah Okimasis from the Eemanapiteepitat Indian Reserve." Something having to do with "Jeremiah Okimasis, first Indian to win this gruelling contest in its forty-seven-year history..."

The scene described above is a direct reference to one of the first scenes in the novel, when Abraham Okimasis becomes the first Indian to win the Dog Derby. The events play nearly exactly the same, with the winner being blinded with the desire to win, and becoming terribly confused once the dream is finally realised. In this way, Jeremiah repeated his father's achievement. In this instance, the circular concept of time was realised by passing of genes and passion.

Abraham's death deeply affects both of his sons. Gabriel decides to use this experience as a story-line for a dancing performance, in which he plays the lead role. The spectacle tells the story of Abraham's ascension to heaven, where he meets God. The reader may at first be confused, as the hunter is described waking up in his coffin, wondering where he is. This resurrection itself can be seen as part of a cycle. In the scene, Gabriel becomes his father by playing his role. Just like Jeremiah, Gabriel continues his father's legacy in his own way. This 
plot device is strengthened even further through the description of Gabriel's death. Ravaged by disease, at his deathbed, the dancer has a vision of taking part in a sled dog race. The vision is a nearly exact, word for word repetition of the opening scene of the novel, where it is Abraham, who is racing to become a champion. In this powerful scene, Gabriel once again becomes his father, and the past connects with the present. His deathbed scene is also reminiscent of his father's. Jeremiah does not want to let a priest come into the room with his dying brother. At the time of Abraham's death, the brothers were also upset with the presence of a priest. In the end, both Gabriel's and Abraham's souls are taken away by the Fur Queen.

One of the major themes of the novel is the influence of a person's childhood on their adult life. Jeremiah and Gabriel are both sent to a residential school run by priests. They are uprooted from their culture. Their hair is cut, their names are changed, they are forbidden to use their language. Held to the moral standards imposed on them by the priests, the boys are unable to resist, and can only adapt to the new situation. Their parents are pious believers themselves, and do not provide much support for their children. The boys are physically and sexually abused by the predatory Father Lafleur:

Gradually, Father Lafleur bent, closer and closer, until the crucifix that dangled from his neck came to rest on Gabriel's face. The subtly throbbing motion of the priest's upper body made the naked Jesus Christ - this silver of silver light, this fleshly Son of God so achingly beautiful - rub his body against the child's lips, over and over and over again. (...) He shut his eyes tight. He held his breath. (78-79)

Gabriel and Jeremiah are both victims of the priest's attacks. The older brother, however, chooses not to remember them in a defence mechanism, which allows him to go through life without facing his demons:

Jeremiah opened his mouth and moved his tongue, but his throat went dry. No sound came except a ringing in his ears. Had this really happened before? Or had it not? But some chamber deep inside his mind slammed permanently shut. It had happened to nobody. He had not seen what he was seeing. (80)

The events of the boys' childhood echo throughout the novel in every decision they make. They shape their life choices and lifestyles. Their past haunts them every step of the way.

After graduating from school, Jeremiah further pursues a career as a musician. However, his life seems empty. He does not feel a part of any community, and he struggles to rediscover his identity. His days are filled with overwhelming loneliness, as he does not belong anywhere. His passion for music becomes an obsession as he practices playing piano until his fingers bleed (107). He rarely leaves his apartment. He becomes asexual, disinterested in anything other than music, and he succumbs to "inexpressible loneliness" (159). He even considers taking 
his own life as a desperate measure (170). Jeremiah's disinterest in pursuing relationships with women is further intensified by him reading accounts of violence against women (107), (132). Belghiti (2009: 2) argues that Jeremiah begins to associate all manifestations of heterosexual love with violence. Due to the events of his childhood, the same might be said about homosexual love. Only with the help of another character, Amanda Clear Sky, does he slowly recover from this troubled state. Amanda belongs to the Ojibwe tribe but, unlike Jeremiah, she has not discarded her heritage. Because of her, Jeremiah is able to rediscover his roots and become healed. The two eventually fall in love with each other. This is another instance, in which the image of a circle returns. In order to move forward, Jeremiah has to go back to his origins and has to recover the traumatic childhood memories. Jeremiah's recovery is concurrent with his rediscovery of community life. Thanks to Amanda and her people, he is no longer alone. This plotline, similarly to the epidemic in Ravensong, stresses the invaluable role of community in the characters' lives. Without other people, the mechanism of reciprocal support cannot exist. A solitary person has to rely on themselves, which drastically reduces their chance of survival. Jeremiah's alienation may further be connected with the environment in which he finds himself. Smith explores the Indigenous urban experience in the novel. She notes that in many cases, a character's separation from the more natural, rural landscape and their placement in an urban environment, is associated with the feeling of loneliness and even fragmentation of identity (2009: 146). Because of the sheer size of a city, urban communities often become dispersed and struggle to remain whole.

Contrary to Jeremiah, Gabriel engages in excessive sexual activity with randomly met men, often priests. He frequents places of dubious reputation, such as the Hell Hotel or the Rose bar. He enters into a relationship with his dancing mentor, Gregory Newman. Some scholars draw parallel between Gregory and Father Lafleur, pointing out that Gabriel never escapes the cycle of abuse (Fee 2003). When Jeremiah finds out about his brother's promiscuous lifestyle, he is utterly horrified: "How can you let someone do what that disgusting old priest did to you? How can you seek out... people like that?" (207). Gabriel responds to his brother's accusations by attacking him back: "You'd rather diddle with a piano than diddle with yourself. You're dead, Jeremiah. At least my body is still alive." (207). The traumatic events of the past leave marks on both brothers. They deal with the trauma in different ways, but the abuse constantly haunts them, as they are stuck in a loop. By the end of the novel, Jeremiah manages to break free of this prison, but the consequences for Gabriel are much more severe. His wanton lifestyle leads to his premature death.

Finally, it is important to mention the title character of the Fur Queen, as well as the monstrous Weetigo: two symbolic characters appearing throughout the novel. The Fur Queen appears first at the very beginning of the story. During the Trappers' Festival in Manitoba in 1951, there is a Fur Queen Beauty Pageant organised. The title goes to Julie Pembrook, who then presents the trophy for winning the World Championship Dog Derby to Abraham Okimasis. Abraham is entranced by the woman's radiant beauty. She kisses him on the cheek and they have a photo taken together. The Fur Queen begins as a regular white woman. 
However, that quickly changes, as she becomes another incarnation of the Indigenous trickster character, known in Cree as Weesageechak. The trickster reappears on multiple occasions keeping a watchful eye on the boys but, in a true trickster fashion, not helping them much. She is there when the brothers are abused by Father Lafleur (73). She welcomes them when they return home during school breaks (110) and she guides them when they get lost in town (117). She watches them as they argue and beat each other up (208), observes as Jeremiah wins the Crookshank Memorial Trophy (214). She visits Abraham on his deathbed (228). Finally, she arrives to take Gabriel's soul with her. The most significant of all the Fur Queen's appearances however, has to be the instance when she appears before drunk Jeremiah after Abraham's death:

"Hello, Jeremiah," someone cooed with a voluptuous, full-fleshed languor. Like a curtain, the mist parted. And there, leaning against a grand piano made of ice stood a torch-singing fox with fur so white it hurt the eyes. (...) She was far too spectacular: missile-like tits, ice-blond meringue hair. (...)

"Name's Maggie. Maggie Sees. It used to be Fred but it bored the hell outta me so I changed." With an arm sheathed in white chiffon, she flipped her bushy tail, like a boa, over her slender shoulder. Her eyeshadow was so thick she could barely lift the lids. (231)

Metamorphosis and transformation are hallmarks of the Indigenous trickster. It is difficult to say with all certainty if Maggie Sees is a transgender character or maybe a drag queen. The trickster by definition avoids gender categorisation and labelling. In terms of circular time, she is a recurring character reminiscent of Ravensong's Raven, but with a modern twist.

Another recurring mythological character, which appears in the novel is the Weetigo. The brothers recall a story about the Weetigo and Weesageechak that they heard from their aunt Black-eyed Susan (121-122). The Weetigo was a human-eating monster, an evil spirit that forced people to perform acts of cannibalism. It was killed by Weesageechak, who took the shape of a weasel. The imagery of the Weetigo and humans devouring humans resurfaces in many places throughout the novel. The monster can be associated with Father Lafleur, who abused helpless children. This is exactly how Jeremiah perceives the priest (79). As people bitten by the Weetigo turn into the monster themselves, Gabriel may also be seen as an incarnation of the beast. While practicing ballet with some children, Gabriel tries to avoid looking at them, as he feels like the Weetigo (152). Jeremiah experiences a similar sensation later in the story (271). Elsewhere, the television is compared to the monster, which invaded the brothers' hometown of Eemanapiteepitat and devoured its soul (187). Another time, it is discerned in the frenzy of consumerism, as they observe the behaviour of people in a shopping mall (122). Finally, AIDS may also be seen as an incarnation of the flesh-eating monster, leading to Gabriel's death. Despite being aware of his disease, Gabriel continues to engage in unprotected sex and spreads the virus further. The Weetigo and its cannibalistic tendencies are another examples of temporal circles within the novel. The whole concept of a monster, which attacks other people to 
also turn them into monsters, is based on a cycle. Both Gabriel and Jeremiah fell victim to the Weetigo and, in a way, both of them became the Weetigo.

Moreover, the presence of mythical characters in both novels, also signifies the presence of mythological time. As Highway points out in his lecture, mythology lies halfway between lie and truth. It could also be related to the concepts of Indigenous narrative memory and oral history. McLeod (2000: 52) explains that "[i]n Cree culture, the boundaries of reality extend between the dream state and the consciousness state." He argues that the Trickster is a representation of nonlinear consciousness. Every appearance of the character can therefore be seen as a challenge to a linear perception of time and a signal which suggests that "everything is not as it seems" (McLeod 2000: 53). Stories often describe events which from a Western perspective may seem dreamlike or supernatural. The very presence of these elements is likely to disqualify the entire narrative as a historical account. Historians challenge the credibility of oral history calling it subjective. However, oral history and narrative memory do not follow the same set of rules as Western history. Elders' stories are told from a personal perspective. Storytellers are often hesitant to discuss events that are not part of their personal history. When a story is retold by another person, it is important to credit the original source. For these reasons, Indigenous storytelling may often be seen as more believable than archival documents written by scholars or anthropologists from a privileged outside perspective. The events and characters of both Ravensong and Kiss of the Fur Queen may be seen as part of that narrative memory, halfway between history and fiction.

\section{The circular concept of time as an expression of Indigenous literary nationalism}

Conveying the circular concept of time as well as other features of orality in literature might be seen as an example of Indigenous literary nationalism. The ideas of Indigenous literary nationalism were first expressed in an article by Simon J. Ortiz (1981) of the Acoma Pueblo tribe in the United States. In the article, Ortiz argues that the Indigenous peoples transformed European culture and literary traditions in order to make them their own. Ortiz sees this practice as a form of resistance against colonialism and oppression:

[Christian religious rituals] are now Indian because of the creative development that the Native people applied to them. Present-day Native American or Indian literature is evidence of this in the very same way. And because in every case where European culture was cast upon Indian people of this nation there was similar creative response and development, it can be observed that this was the primary element of nationalistic impulse to make use of foreign rituals, ideas, and material in their own - Indian - terms. Today's writing by Indian authors is a continuation of that elemental impulse. (Ortiz 1981: 121) 
Indeed, introducing the circular perception of time as well as other orality features is a creative development of literature in an Indigenous direction. This leads to the creation of a new style of writing, a reinvention of fixed literary traditions.

Over the years, many Indigenous writers and critics have voiced their displeasure with how European literary standards are used to analyse and criticise literatures of other cultures. According to Agnes Grant (1990: 124), "We have an idea of what 'good style' is, this idea having fixed and unchanging attributes. We use written European tradition and apply it to literature from all cultures. This effectively precludes members of other culture groups from holding influential literary positions and also ensures a continuation of existing criteria." Barbara Godart (1990: 184) criticises the Canadian literary canon for not including texts written by Native authors, but instead trying to paint a universal image of Canadian literature. She adds that the canon should reflect the diversity of Canada, where authors from marginalised groups are able to create texts in their unique style, without the need of confronting their works with a pre-established norm.

On a more political note, there might also be a connection between the circular worldview and the concept of Indigenous resurgence. Leanne Simpson (2011: 17) talks about the need for a shift of focus in Indigenous movements, from "resistance and survival, to flourishment and mino bimaadiziwin", which translates to "the art of living a good life" or "continuous rebirth." Her book reverberates with words such as "resurgence," "re-creation," "renaissance," "regenerate," "reestablish," "reclaim," etc. She advocates for an Indigenous political movement based on Indigenous values and beliefs.

It begins with how we treat ourselves and our family members-how we make decisions that honour the voices of all of our family members; how we respect individual autonomy and sovereignty (...). These relations then spiral outward to our communities and our nations. They extend into the network of relations in the implicate order and set up cycles of non-violence for the generations yet to come. This teaching is often visualized as a spiral, starting with the individual and radiating upwards and outwards with the circles gradually becoming larger. But according to our teachings, the spiral radiates in all seven directions-inward, outward in the four cardinal directions, upwards, downwards and through time. (Simpson 2011: 108)

Although this paper focuses mainly on depictions of time, it is clear that circles and cycles are not limited to the realm of literature. They are an inherent part of Indigenous worldview, which plays an important role in many areas of life.

By depicting the circularity of time in their novels, Lee Maracle and Tomson Highway made a conscious decision to depart from the European writing traditions. Both Ravensong and Kiss of the Fur Queen are rich in other features of oralised literature and stylistic choices that differentiate them from non-Native writing. Therefore, the novels could be seen as contributing to the Indigenous literary nationalism and Indigenous resurgence movements. 


\section{Conclusions}

Both Ravensong and Kiss of the Fur Queen use a variety of techniques to convey the concept of circular time. These techniques are consciously used by the authors. They do not invoke the circular image of time directly, especially since the novels do not focus specifically on time, but rather draw their temporal circles in the background. Both texts contain one or more vision scenes, in which a character simultaneously witnesses the events of the present, past, and future. These visions directly challenge the linear perception of time. However, the most common literary devices used for depicting the circular time are repetitions of phrases or entire scenes, recurring events and characters. Although the novels cover seemingly unrelated topics, upon a closer read, many parallels may be drawn between them. The titles of the novels already introduce characters crucial for the story. In both cases, the eponymous character turns out to be the shape-shifting trickster. The trickster in Ravensong is more sinister than the one in Kiss of the Fur Queen. However, due to the common Indigenous heritage of the two authors, it may be even claimed that Raven and the Fur Queen are one and the same character. The characters in the novels struggle with various issues and find strength in their Indigenous heritage. Both novels use also very similar techniques for depicting the circular time. They describe similar events repetitively, while still allowing the story to progress. By combining the skilful use of repetition with Indigenous mythology, captivating story, and relatable characters, the authors have managed to create novels which clearly convey the ideas of circular time but allow it to remain in the background and play a supportive role in the texts.

\section{References}

Belghiti, Rachid (2009) Choreography, sexuality, and the Indigenous body in Tomson Highway's Kiss of the Fur Queen. Postcolonial Text 5(2), 1-17. http://postcolonial.org/ index.php/pct/article/view/1006 Accessed on 15.02.2018.

Cahill, Thomas (2010) The Gifts of the Jews: How a Tribe of Desert Nomads Changed the Way Everyone Thinks and Feels. New York: Knopf Doubleday Publishing Group.

Cullingham, Haley (2016) "We have the same language, but definitely different rules": an interview with Lee Maracle. https:/ / hazlitt.net/feature/we-have-same-language-definitely-different-rules-interview-lee-maracle Accessed on 13.02.2018.

Dadey, Bruce (2003) Dialogue with Raven: Bakhtinian theory and Lee Maracle's Ravensong. Studies in Canadian Literature 28(1), 109-131.

Donaldson, Mike (1996) The end of time? Aboriginal temporality and the British invasion of Australia. Time and Society 5(2): 187-207.

Fee, Margery and Sneja Gunew (2004) From discomfort to enlightenment: An interview with Lee Maracle. Essays on Canadian Writing 83, 206-221.

Fixico, Donald Lee (2013) The American Indian Mind in a Linear World: American Indian Studies and Traditional Knowledge. New York: Routledge.

Godard, Barbara (1990) The politics of representation: Some Native Canadian women writers. Canadian Literature 124(25), 183-225.

Grant, Agnes (1990) Contemporary Native women's voices in literature. Canadian Literature 124(25), 124-132. 
Hampton, Eber (1993) Towards a redefinition of Indian education. Canadian Journal of Native Education 20(2), 261-310.

Hancock, Brecker (2015) An interview with Lee Maracle. http://cwila.com/an-interviewwith-lee-maracle/ Accessed on 13.02.2018.

Highway, Tomson (1998) Kiss of the Fur Queen. Canada: Doubleday Canada.

Highway, Tomson (2003) Comparing mythologies. Ottawa: University of Ottawa Press. http://www.oralhistoryforum.ca/index.php/ohf/article/view/117

Imani, Nikitah Okembe-RA (2012) The implications of Africa-centered conceptions of time and space for quantitative theorizing: Limitations of paradigmatically-bound philosophical meta-assumptions. Journal of Pan African Studies 5(4), 101-111.

Maracle, Lee (1993) Ravensong: A Novel. Vancouver: Press Gang Publishers.

McLeod, Neal (2000) Cree narrative memory. Oral History Forum d'histoire Orale 19.

Niehaus, Damien-Noah (2013) From mythical time to scientific time. The transformation of time in the Middle Ages. https://www.academia.edu/3649776/From_mythical_ time_to_scientific_time._The_transformation_of_time_in_the_middle_ages. Accessed on 30.06 .2018 .

Ong, Walter (2002) [1982] Orality and literacy. New York: Routledge.

Ortiz, Simon J. (1981) Towards a national Indian literature: Cultural authenticity in nationalism. Ethnic Literature and Cultural Nationalism 8(2), 7-12.

Silko, Leslie Marmon (1996) Yellow Woman and a Beauty of the Spirit: Essays on Native American Life Today. New York: Simon \& Schuster, 48-59.

Simpson, Leanne Betasamosake (2011) Dancing On Our Turtle's Back: Stories of Nishnaabeg Re-Creation, Resurgence, and a New Emergence. Winnipeg: ARP Books.

Smith, Lindsey Claire (2009) "With these magic weapons, make a new world": Indigenous centered urbanism in Tomson Highway's kiss of the fur queen. The Canadian Journal of Native Studies XXIX (1\&2), 143-164.

Whitrow, Gerald James (1989) Time in History: Views of Time from Prehistory to the Present Day. Oxford: Oxford University Press.

Michat Kapis is a PhD student at the Faculty of English at Adam Mickiewicz University in Poznań, Poland. His research interests include orality studies and Indigenous literatures. He has a bachelor's degree in South African studies. In his M.A. thesis he analysed a selection of Aboriginal Canadian and South African prose to determine what techniques authors use in order to combine their oral tradition with the technology of writing. At present, he continues his research into orality features in Aboriginal literatures around the world, focusing on how particular tribal affiliations might affect the oralisation strategies and techniques.

Address: Michał Kapis M.A., Center for Canadian Literature, Faculty of English, Adam Mickiewicz University in Poznań, al. Niepodległości 4, 61-874 Poznań, Poland. [e-mail: mkapis@wa.amu.edu.pl] 